\title{
Zika Virus Infection after Returning from Thailand
}

\author{
Viroj Wiwanitkit ${ }^{1, *}$ \\ ${ }^{1}$ Public Health Curriculum, Surin Rajabhat University, Thailand
}

*Corresponding Author: Viroj Wiwanitkit, Professor, Senior Expert, Public Health Curriculum, Surin Rajabhat University, Thailand. Email: wviroj@yahoo.com

Article History: Received: 29 Mar. 2016; Accepted: 19 Apr. 2016; Online Published: 25 Jun. 2016

Cite this article as: Wiwanitkit V. Zika virus infection after returning from Thailand. Int J Travel Med Glob Health. 2016;4(2):69. doi: 10.20286/ijtmgh-04027

\section{Dear Editor}

Zika virus infection is a new problem that is being seen worldwide [1-3]. This disease can be seen in travelers returning from visits to tropical countries. In Thailand, a tropical country in Southeast Asia, the disease has already been reported in some local Thai patients as well as among foreign travelers returning from Thailand [4]. There are at least 2 confirmed cases of Zika virus infection in travelers returning from Thailand $[5,6]$. This number is comparable to the 7 confirmed cases of infection in local Thais [4]. The two cases are Western travelers who visited sea resort areas in Thailand and fell ill during their flight back. Their infection was confirmed as an imported case of Zika virus in their hometowns in Europe and Canada [5, 6]. However, there is no confirmed case of Zika virus infection in any local Thai people living in the visited sea resort areas. This situation can confirm the importance of travel medicine. Travelers to any locations should be aware of the risks of infection despite the lack of reports or documented risk notification on that travel destination. It is recommended that any travelers be informed of the situation at the port of entry by the local public health agency and be warned of the risks of Zika virus infection in each specific area.

\section{Financial Disclosure}

None.

\section{Funding/Support}

None.

\section{References}

1. Joob B, Wiwanitkit V. Zika virus infection and dengue: A new problem in diagnosis in a dengue-endemic area. Ann Trop Med Public Health. 2015;8(4):145. doi: 10.4103/1755-6783.162402

2. Wiwanitkit S, Wiwanitkit V. Acute viral hemorrhage disease: A summary on new viruses. J Acute Dis. 2015;4(4):277-9. doi: 10.1016/j.joad.2015.06.004

3. Wiwanitkit S, Wiwanitkit V. Afebrile, asymptomatic and non-thrombocytopenic Zika virus infection: Don't miss it! Asian Pac J Trop Med. 2016 ;9(5):513. doi: 10.1016/j.apjtm.2016.03.036

4. Buathong R, Hermann L, Thaisomboonsuk B, Rutvisuttinunt W, Klungthong C, Chinnawirotpisan P, et al. Detection of Zika Virus Infection in Thailand, 2012-2014. Am J Trop Med Hyg. 2015;93(2):380-3. doi: 10.4269/ajtmh.15-0022

5. Fonseca K, Meatherall B, Zarra D, Drebot M, MacDonald J, Pabbaraju K, et al. First case of Zika virus infection in a returning Canadian traveler. Am J Trop Med Hyg. 2014;91(5):1035-8. doi: 10.4269/ajtmh.14-0151

6. Tappe D, Rissland J, Gabriel M, Emmerich P, Günther S, Held G, et al. First case of laboratory-confirmed Zika virus infection imported into Europe, November 2013. Euro Surveill. 2014;19(4). pii: 20685. doi: 10.2807/1560-7917.ES2014.19.4.20685 